\title{
The Impact of Digital Technology on Graphic Designer Profession
}

\author{
I Ketut Sutarwiyasa; I Nyoman Agus Suarya Putra; Aniek Suryanti Kusuma
}

Teknik Informatika, STMIK STIKOM Indonesia, Indonesia

http://dx.doi.org/10.18415/ijmmu.v9i2.3459

\begin{abstract}
The presence of all-digital technology has shifted the way people communicate, work and do activities. Therefore, there is a new perspective or paradigm in seeing and assessing. If in the previous era, to design a work, someone used manual work equipment, accompanied by long and complicated stages and processes. In fact, it can only be done by certain people who have certain skills. In the current era with the presence of digital technology, the stages and work processes have begun to decrease significantly, as well as in the field of graphic design. This is certainly a challenge for someone who works as a graphic designer. The formulation of the problems raised in this study includes the impacts and challenges of the graphic designer profession in the era of digital technology. This research uses descriptive qualitative approach. Data was collected through direct observation, interviews, and documentation. Documentation techniques in the field and interviews, allow researchers to analyze data during data collection. The purpose of this research is to answer the impacts and challenges of the graphic designer profession in the era of digital technology. The results of the analysis show that in addition to the positive impact, the development of digital technology on the graphic designer profession also has a negative impact, namely the role of a graphic designer is slowly being replaced by technology itself. Thus, this is a serious challenge for the graphic designer profession, because it involves the continuity of their profession in the future.
\end{abstract}

Keywords: Digital Technology; Graphic Designer; Impact of Technology

\section{Introduction}

Advances in technology, which are marked by digitalization and automation, are a sign of the era of the Industrial Revolution 4.0. This growing trend gives rise to various disruptions that were never thought of before. The presence of all-digital technology has shifted the way people communicate, work and do activities. Therefore, there is a new perspective or paradigm in seeing and assessing. As an illustration, if in previous eras for designing or designing works, a graphic designer used manual work tools, accompanied by long and complicated stages and processes. In fact, it can only be done by certain people who have certain skills. The next period, with the advent of digital technology (computers), the stages and process of designing work have begun to decrease significantly. 
The digital era can be interpreted as a stage of major and radical changes to the production system, where new technology is present that changes the way humans produce things, including the way a graphic designer works. In the previous era, making a graphic design work required special skills that were usually obtained from the world of education, but in the era of digital technology, making a graphic design work does not seem to need special skills. This is because at this time there are many available technologies or instant applications to design a graphic design work. We just have to download it on the internet and it is ready to be used for designing without the need for special learning. Thus, this is a serious challenge for the graphic designer profession, because it involves the continuity of their profession in the future.

\section{Method}

This research is descriptive-qualitative. Data was collected through direct observation, interviews, and documentation. Documentation techniques in the field and interviews, allow researchers to analyze data during data collection. The data collection tools used were interview guides, field notes.

Data from interviews and field observations recorded during data collection were rearranged to look for the impact of the digital technology era on the existence of the graphic designer profession. It aims to break down reality into parts by labeling each field note according to the data information. In this process, data is a unit of information that serves to determine or define categories. After that, an interpretation of the reality and the phenomenon of the impact of the digital technology era on the graphic designer profession was carried out, so that conclusions could be drawn as answers to research questions.

\section{Discussion}

The meaning of profession is still an interesting discussion to discuss, because until now there is still no right word to define the meaning of profession. This is because there is no standard of work or task that can represent it as a profession. Some say that a profession is a person's position even though the profession is not commercial in nature. However, usually there are four jobs that are always associated with the profession, namely medicine, law or advocate, education, and the priesthood (Drajat, 2017).

Arifin stated that profession has the same meaning as the word occupation or work that requires expertise acquired through special education or training (Arifin, 2015). In line with this understanding, Nasihin argues that a profession is a field of work that someone wants or will do. Profession is also defined as a certain position or job that requires special knowledge and skills obtained from intensive academic education. So, a profession is a job or position that requires certain skills (Nasihin, 2018).

The term that later developed in the basic word profession is professional. This professional word is an adjective meaning 'livelihood' and as a noun which means 'people who have expertise such as teachers, doctors, judges and so on'. In other words, a job can be said to be professional when the work is done by those who are specially prepared for it and not the work done by those who cannot get another job.

According to Hamid, professionalism refers to the commitment of members of a profession to improve their professional abilities and continuously develop the strategies used in doing work that is in accordance with their profession (Hamid, 2017). On the other hand, professionalism refers to the attitude of members of the profession towards their profession and the degree of knowledge and expertise they have in order to carry out their work. So, a professional will not want to do something that is not in his field. In this regard, a professional worker can be distinguished from an amateur worker even though they 
both master a number of certain work techniques and procedures. because a professional worker has a philosophy to address and carry out his work. Profession is a job that is prepared through a process of education and training. The higher the level of education that must be fulfilled, the higher the degree of the profession it carries. The level of recognition of professionalism is highly dependent on the expertise and level of education taken. Referring to the reviews above, it can be concluded that what is called a profession is a job or skill that requires intellectual competence, scientific behavior based on certain knowledge and skills, is in accordance with the needs and demands of the labor market, and is obtained by someone through the process of education and academic training in universities, as well as the graphic designer profession.

Graphic design is a form of visual communication (Visual Communication Design) that uses images to convey information or messages as effectively as possible. In graphic design, text is also considered an image because it is the result of abstraction of symbols that can be sounded. graphic design is applied in communication design and fine art. Like other types of design, graphic design can refer to the manufacturing process, design method, resulting product (design), or the discipline used (Kusrianto, 2007). A graphic designer uses sketches to explore complex ideas precisely, and furthermore he has the freedom to choose the tools to complete them by hand or computer. After the design/work is finished, it is usually printed using existing technology, such as digital printing, offset printing, screen printing, and so on. A concept or idea is usually not considered a design before it is realized or expressed in a visual form (Tinarbuko, 2008).

Graphic designer or often referred to as a graphic designer (English: graphic designer) is a profession engaged in graphic design that aims to create illustrations, typography, photography, or motion graphics. A graphic designer creates work for publishers, print and electronic media, such as an advertisement for a product, or a brochure for a company. They are responsible for a display to make it look attractive, which can be applied in various forms of promotional materials related to products and the public. Graphic designers are tasked with conveying an information desired by the product/client in the form of an attractive design (Tinarbuko, 2008).

Currently, the work of graphic designers with various levels of creativity is displayed from the moment they wake up, until they go to sleep again. When we wake up, we can definitely feel the aroma of the design in the room. Bed linen designs, calendar designs, interfaces, cell phones, even slippers. Entering the bathroom, various logos are displayed scrambling for our attention, ranging from toothpaste, shampoo, toothbrush, bath soap, mustache trimmer, to facial cleanser. Going to school or work, we see billboards, flyers on the road, stickers on the back of public transportation, poster designs, to the touch of graffiti on the tailgate. Entering the canteen, finding the logo and all branding efforts from food, from burgers, bread, instant noodles, bottled tea, soft drinks, to toothpicks, even the packaging design requires a graphic designer's touch.

Although every day our eyes seem to be "forced" to see the beauty of logos, advertisements, brochures, product info, and instruction manuals and others, not a few are eye pollution because they are just made, without a clear concept. A graphic designer should be able to bridge the idea of a concept with an artistic image, so as to produce works that not only succeed in capturing the attention of the audience, but also have aesthetic value. Well, to create media like that requires graphic designers to equip themselves with the skills that must be possessed through the educational process, which is one of the requirements to become a professional.

In designing a design, a designer does not merely draw, doodle, paint, or paste pictures. Behind a design there is always a philosophy, why the design is made that way. There are values and considerations that are made and loaded by a designer such as the selection of colors, writing, and the composition of the placement of image elements so that the aesthetics of the design is maximized. All of these things require ideas and experience, and ideas are very valuable. Ideas are not just things that are 
easy to get and apply. An idea requires a lengthy brainstorming process with various considerations. If the idea does not fit and deviates from the original goal, then a designer will repeat to the beginning to look for new ideas (Christopher, 2016).

Experience must be obtained not in a short time. A graphic designer seeks years of experience to be able to create a design that is more attractive, better, and easier to convey a message. This also shows that what we buy is the value of a design and the effort of the designer in creating the design. In comparison, when we go to a restaurant, do we pay for the food we buy only for the raw materials? certainly not. We appreciate the value of the food so that we are willing to spend money that is sometimes quite fantastic to get it (Christopher, 2016).

In addition to the above, being a graphic designer is not as easy as many people imagine, it takes special knowledge which is usually taken through education. The cost of taking graphic design education/college is quite expensive, because there are lots of lecture materials with practicals that use quite expensive facilities and infrastructure, such as computers, cameras, drawing tables, paper, and ink.

However, along with the presence of digital technology, it has shifted the public's perspective in responding to the graphic designer profession. As an illustration, in the previous era, to design a graphic design work required a long and complicated process, even it could only be done by people who had special skills. However, in this era of digital technology, many people think that making graphic design work does not need special skills, it is enough with instant applications that can be downloaded for free from the internet. Opinions like this can be a threat to the continuity of the graphic designer profession in the future.

The impact of the digital era is not only aimed at the production method, but has an impact on other things related to social, economic, cultural, and even political problems. In the context of graphic design, the digital era is understood that everything is computerized, or the automation and reconciliation of data in order to realize an intelligent design work. The digital era will continue to bring about many changes in the world of graphic design that cannot be contained. There are at least three things that distinguish the digital era from the previous industrial era in the graphic design world, namely: First, design innovation develops and is distributed much faster than before. Second, the decrease in production costs, causing changes to the entire production system, management, and governance. Third, changes occur globally and have a major impact in almost all countries in the world (Pudjasworo \& Dkk, 2019).

With this reality, the digital era will increase efficiency in the graphic design field, especially in terms of shifting the human workforce (HR) towards digitalization. This reality is a form of challenge that needs to be addressed, including by graphic designers. The digital era encourages a change in mindset in technology and network-oriented graphic design activities. Networks play an important role in many activities, and digital information is a major source of design. In addition, the network becomes a pattern of interaction in various ways. It should be noted that the digital era forces humans to enter two worlds, namely the real world and the virtual world (virtual). The internet of things, which is a spirit in this era, conditions humans personally and communally, which is very dependent on the virtual world (Purwadi, 2020).

To deal with the above, there is no other way except that graphic designers have to change the old perspective to a new one. Perspective is a conceptual framework or idea in seeing a phenomenon that can affect a person's attitudes and actions. Regarding the perspective in dealing with the digital era, if you view the presence of the digital era as something negative, then the digital era will become a serious threat to the existence of the graphic designer profession. This is in line with what Harsanto said, that the digital era will crush many people, even thousands of people will lose their jobs (Harsanto, 2019). Due to the rapid development of digitalization technology, the role of graphic designers will gradually but surely be taken over by automatic machines and other parties. The number of mobile applications that can be downloaded via smartphones makes it easier for anyone to edit videos, arrange design layouts, and even 
draw digitally. With the advancement of digital technology, now anyone can become a graphic designer without having to learn it through formal educational institutions. This is certainly a challenge for those who work as a graphic designer.

However, if you view the presence of the digital era as something positive, then the digital era is something that can provide many opportunities and advantages for a graphic designer. Opportunities caused by sophisticated technology that can facilitate access in all sectors of life. Many conveniences and innovations are obtained with the support of digital technology, including technology in the world of graphic design. In short, the digital era instills intelligent technology that can connect with various areas of human life.

For a graphic designer, facing the digital era must be accompanied by attitudes and efforts to increase skill competence, especially mastery of digital technology, communication skills, the ability to work collaboratively, and the ability to continue to learn adaptively to environmental changes. The world of graphic design is not limited to the use of computer software or mobile applications alone, but is closely related to sciences such as typography, nirmana, illustration, layout, and others. More than that, graphic design also includes sciences such as psychology, communication, marketing, branding to culture (Wibowo, 2011). This is what is often forgotten by those who do not study graphic design and only rely on skills in operating digital technology.

The shift of human labor towards digitalization is a form of challenge that must be responded intelligently by graphic designers, because in a new paradigm or perspective, it does not only look at the economic aspect, but also on the value of design criticism and humanism. Although it must also be admitted that the economic problem remains an energy for graphic designers, because without the economy, graphic designers are just an intellectual exercise. However, an economy without design is like a body without a soul, or humans without cultural values. Basically, economics and design have the same goal, namely improving the quality of human life.

Design has become a mainstay and a stimulus that has a positive impact on economic growth in Indonesia. Therefore, the Joko Widodo government formed a forum called the Creative Economy Agency (Bekraf) to respond to the enormous economic potential that exists in Indonesia's creative industries (including the graphic design field). The government is aware that the role of design is important for economic growth and the national innovation system. The world community is currently paying close attention to the digital era, because there are various opportunities and challenges there.

\section{Conclusion}

The emergence of the digital technology era is of course accompanied by the emergence of its impacts, both positive and negative. The positive impact of digital technology in general is indeed to make the process of doing all things faster and shorter, and of course making the work produced better. Compared to the positive impacts that exist, the emergence of negative impacts from the development of digital technology is of course also unavoidable. One of them is that technology can replace the role of humans, as well as in the field of graphic design. With digital technology, making a graphic design work as if it can be done by anyone. The number of mobile applications that can be downloaded via smartphones makes it easier for anyone to edit videos, arrange design layouts, and even draw digitally.

The digital age is a revolution that is fundamentally changing the way we live, work and relate to one another. The changes are dramatic and occur at an exponential rate. Changes that are very influential in life compared to the previous industrial revolution era. Many things that were not thought of before, suddenly appear and become new innovations, and open up a very large business area. The presence of the digital era has indeed brought new businesses, new jobs, and even new professions that were 
previously unthinkable. For a graphic designer, facing the digital era must be accompanied by attitudes and efforts to increase skill competence, especially mastery of digital technology, communication skills, the ability to work collaboratively, and the ability to continue to learn adaptively to environmental changes. Therefore, it should be used as an opportunity for graphic designers, not as a threat.

\section{References}

Arifin. (2015). Kapita Selekta Pendidikan (Islam dan Umum) (2nd ed.). Bumi Aksara.

Christopher, R. (2016). Kalau Ada Desain Gratis, Kenapa Harus Bayar? Kompasiana. https://www.kompasiana.com/has1/5707752360afbd3c12476a64/kalau-ada-desain-gratis-kenapaharus-bayar

Drajat, M. (2017). Etika Profesi Guru. Alfabeta.

Hamid, A. (2017). Guru Profesional. Jurnal Al-Falah, 17(2).

Harsanto, P. W. (2019). Sandyakala: Prosiding Seminar Nasional Seni, Kriya, dan Desain. Desain Komunikasi Visual (DKV) Dalam Era Revolusi Industri 4.0.

Kusrianto, A. (2007). Pengantar Desain Komunikasi Visual. ANDI.

Nasihin, S. (2018). Profesi Guru dalam Konsep dan Teori. Jurnal Administrasi Pendidikan, 8(2).

Pudjasworo, B., \& Dkk. (2019). Seni \& Revolusi Industri 4.0 ISI Yogyakarta dalam Pusaran Virtual. BP ISI.

Purwadi, I. (2020). Prospek Dan Tantangan Industri Penerbitan Jurnal Dan Prosiding Melalui Teknologi E-Publishing Di Era Digital. Jurnal BACA, 41(1).

Tinarbuko, S. (2008). Semiotika Komunikasi Visual. Jalasutra.

Wibowo, H. B. (2011). Relasi Antara Perguruan Tinggi Desain Komunikasi Visual (DKV) di Indonesia dengan Industri DKV. Jurnal Humaniora Binus University, 2(1).

\section{Copyrights}

Copyright for this article is retained by the author(s), with first publication rights granted to the journal.

This is an open-access article distributed under the terms and conditions of the Creative Commons Attribution license (http://creativecommons.org/licenses/by/4.0/). 